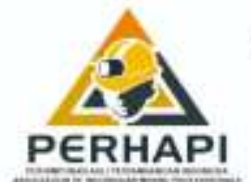

INDONESIAN MINING PROFESSIONALS JOURNAL

PERHAPI, Komplek Rukan Crown Palace Blok D. 09

II. Prof. Dr. Soepomo, SH No. 231. Tebet - Jakarta Selatan 12870

Telp : 021-83783766, Email : jurnol.perhapi@gmai.com

https:/fumal.pertapl.or.id/index.php/impi

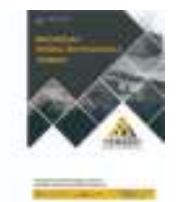

\title{
MANAJEMEN PELEDAKAN PADA KONDISI HOT GROUND DI TAMBANG TERBUKA
}

\author{
${ }^{1)}$ Madinatul Arbi 2)Chani Pradasara dan ${ }^{3)}$ Slamet Rachman Jaka \\ 1,2) Technical Service Engineer, PT. Multi Nitrotama Kimia \\ 3)Manager Technical Service, PT. Multi Nitrotama Kimia
}

Artikel masuk : 17-04-2021 , Artikel diterima : 17-04-2021

Kata kunci :

Peledakan, Elevated Temperature, Reactive Ground, Hot Ground

Keywords: Blasting, Elevated Temperature, Reactive Ground, Hot Ground

\begin{abstract}
ABSTRAK
PT Multi Nitrotama Kimia merupakan salah satu perusahaan jasa pertambangan yang bergerak pada bidang penyedia jasa peledakan dan penjualan bahan peledak terbesar di Indonesia. PT Putra Perkasa Abadi Jobsite Alam Bara Jaya Pratama merupakan salah satu customer dari PT Multi Nitrotama Kimia yang tengah menghadapi tantangan untuk melakukan peledakan pada area yang disinyalir merupakan area Hot Ground dan atau Reactive Ground. PT Putra Perkasa Abadi Jobsite Alam Bara Jaya Pratama bekerjasama dengan PT Multi Nitrotama Kimia dalam mengelola peledakan pada kondisi sesuai dengan klasifikasi kondisi (termal) batuan. Penelitian tahap awal dilakukan dengan pengambilan sampel pada area terkait dan dilakukan Pengujian Isothermis. Sampel diuji dengan waktu pengamatan 48 jam, di Laboratorium PT. Multi Nitrotama Kimia Cikampek. Pengujian ini bertujuan untuk menentukan unsur reaktivitas pada sample batuan. Kemudian dilakukan pengukuran temperatur lubang pada area tersebut. Proses pengukuran temperatur bertujuan membantu mengetahui suhu secara gradual berdasarkan tingkat kedalaman (top hole, middle hole dan bottom hole) dengan metode elevated temperature. Dengan adanya manajemen peledakan yang komprehensif pada area Hot Ground dan atau Reactive Ground, peledakan dapat berjalan dengan aman dan meningkatkan optimalisasi peledakan.
\end{abstract}

*Penulis Koresponden: arbi@mnk.co.id

Doi : https://doi.org/10.36986/impj.v3i1.40 


\section{ABSTRACT}

PT.Multi Nitrotama Kimia is one of the mining service company that provide blasting service and explosive sales in Indonesia. PT Putra Perkasa Abadi Jobsite Alam Bara Jaya Pratama is one of PT Multi Nitrotama Kimia's customer, dealing with blasting in Hot Ground or Reactive Ground area. Furthermore, PT Putra Perkasa Abadi Jobsite Alam Bara Jaya Pratama collaborate with PT Multi Nitrotama Kimia in blasting management according to rock thermal classification.

\section{PENDAHULUAN}

PT Multi Nitrotama Kimia (MNK) merupakan perusahaan yang bergerak dalam supply bahan peledak dan jasa peledakan, dimana sudah memiliki banyak pengalaman dan berkerjasama dengan banyak perusahaan tambang di Indonesia. Salah satu komponen dalam unit bisnis kami, yaitu tim yang bergerak pada bagian Technical Support \& Services dengan kompetensi sesuai bidang keahliannya.

Berdasarkan Keputusan Menteri ESDM Nomor 1827 Tahun 2018, Lampiran II Pedoman Pengelolaan Teknis Pertambangan, dalam hal pemberaian batuan dengan menggunakan metode pemboran dan peledakan dibuat kajian teknis yang mana salah satunya adalah mengenai analisa Hot Ground dan atau Reactive Ground pada kegiatan peledakan. Selanjutnya, PT. Multi Nitrotama Kimia khususnya Technical Services Department melakukan kegiatan
Preliminary research is done by taking sample from the concern area and doing Isothermis Test. Sample is being observed 48 hours in PT Multi Nitrotama Kimia Lab. This test aim to decide the reactive element in rock sample. Then, the hole temperature in concern area is measured. By measuring the hole temperature with elevated temperature method, we will know the hole temperature gradually (based on the depth - top hole, middle hole, and bottom hole). With comprehensive blasting management in Hot Ground or Reactive Ground area, blasting will be done safely and increase blasting optimization.

pemantauan dan analisis untuk dapat mengeluarkan rekomendasi teknis penanganan Hot Ground dan atau Reactive Ground.

Kondisi tanah pada area peledakan perlu diketahui untuk pemilihan produk bahan peledak yang sesuai sebagai persyaratan penting dalam operasi peledakan. Ada empat kemungkinan kondisi tanah pada lubang ledak ketika diisi bahan peledak. Ada 4 (empat) klasifikasi kondisi batuan yang representative kondisi isothermal tersebut, antara lain:

a. Kondisi tanah tidak menimbulkan lubang panas dan tanah tidak reaktif bila diisi bahan peledak. (kondisi normal)

b. Kondisi tanah tidak menimbulkan lubang panas, tetapi tanah reaktif bila diisi bahan peledak.

c. Kondisi tanah menimbulkan lubang panas, tetapi tanah tidak reaktif bila diisi bahan peledak.

d. Kondisi tanah menimbulkan lubang panas dan tanah reaktif bila diisi bahan peledak.

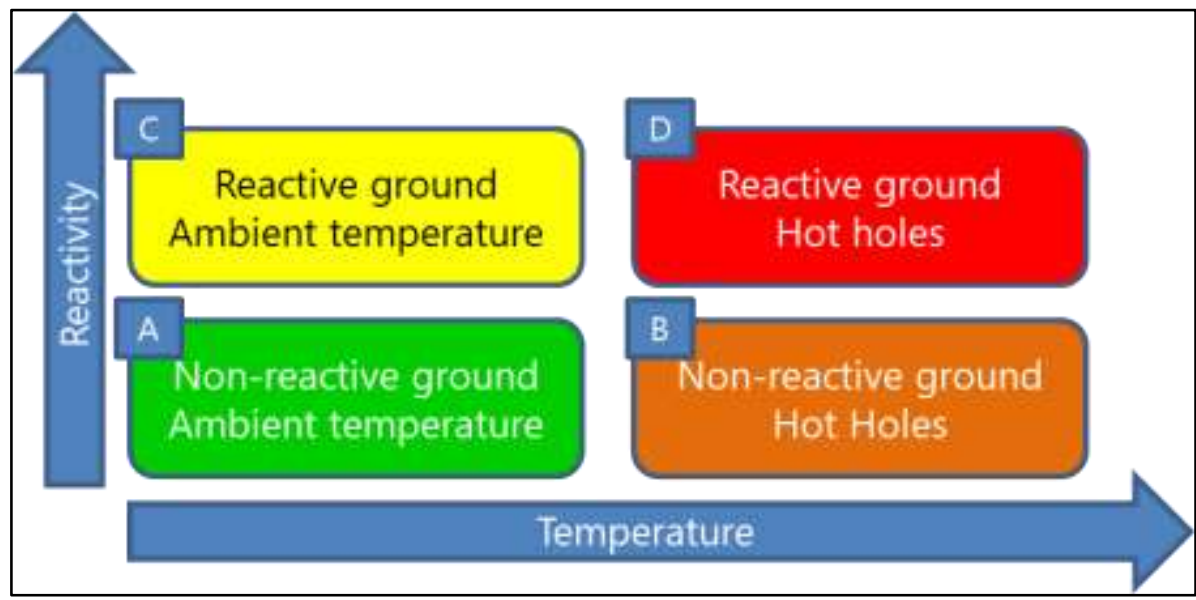

Gambar 1. Klasifikasi Kondisi Batuan

Dalam kondisi suhu dalam lubang ledak lebih besar dari $55^{\circ} \mathrm{C}$, lubang tersebut diidentifikasi sebagai "lubang panas" dan perlakuan peledakan khusus diperlukan ketika memuat lubang tersebut dengan bahan peledak. Jika "lubang panas" tidak diidentifikasi dengan baik dan tidak dimuat sesuai dengan praktik pemuatan yang diperlukan, lubang tersebut dapat meledak secara spontan (premature detonation) dengan konsekuensi yang sering kali membawa bencana.
Penelitian ini berawal dari temuan lubang panas di Pit 1 sebanyak 3 kali. Berdasarkan tinjauan lapangan, terlihat muncul asap dari lubang ledak tersebut dan saat dilakukan pengukuran suhu lubang ledak menggunakan alat ukur Thermo Gun pada permukaan didapatkan nilai suhu sekitar $44-45^{\circ} \mathrm{C}$ sedangkan pada lubang ledak normal suhu paling tinggi mencapai $34^{\circ} \mathrm{C}$. 
Pengujian Isothermis di Laboratorium PT. Multi Nitrotama Kimia Cikampek dilaksanakan pada tanggal 25 - 29 April 2020, masing- masing sample diuji dengan waktu pengamatan 48 jam. Pengujian ini bertujuan untuk menentukan unsur reaktivitas pada sample batuan. Sedangkan untuk pengukuran
Elevated Temperature lubang panas dilakukan pada tanggal 20 Juni 2020. Proses pengukuran Elevated Temperature ini bertujuan membantu mengetahui suhu secara gradual berdasarkan tingkat kedalaman (top hole, middle hole dan bottom hole).

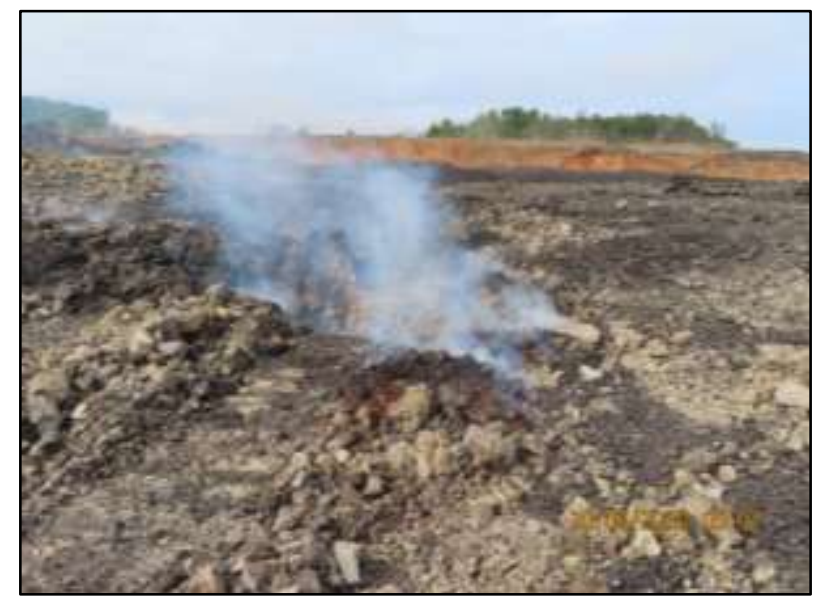

Gambar 2. Lokasi Pemantauan (Pit 1)

\section{METODOLOGI PENELITIAN}

\section{Pengambilan Sample Batuan di Lapangan}

Sampling tanah dilakukan untuk mengetahui unsur yang terkandung pada lokasi yang disinyalir merupakan Hot Ground dan atau Reactive Ground tersebut terutama terkait kandungan sulfidanya. Metode pengambilan sampel dan pengujian ini akan memberikan informasi unsur reaktivitas tanah / batuan pada lokasi tersebut. Prosedur pengambilan sample batuan yang dilakukan di lapangan adalah sebagai berikut:

1. Mempersiapkan peralatan terkait penyimpanan dan penamaan sample seperti: plastik sample, kertas label, pen / spidol, dll.

2. Mempersiapkan peralatan untuk pengambilan sample seperti: skop, palu geologi, dll.

3. Memastikan peralatan pada point 1 dan 2 siap dan layak digunakan

4. Memastikan sample yang diambil dalam fresh condition (bukan kondisi batuan yang sudah terekspos lama) dan bersih dari kontaminan asing yang bisa mempengaruhi hasil.

5. Memastikan sample ditangani dan diperlakukan dengan baik dan benar serta dimasukkan dalam tempat/wadah sample yang memadai.

6. Untuk Uji Lab, berat sample minimal yang diambil adalah $1 \mathrm{~kg}$ masing-masing representative area.

7. Untuk Uji Reactive Ground Bucket Test Sample, sample yang diambil adalah cutting bor atau sample utuh yang sudah dihaluskan dengan berat minimum $1 \mathrm{~kg}$.
8. Memastikan diberikan label yang representative lokasi pengambilan.

9. Memastikan dilakukan oleh pekerja dan di bawah pengawas area yang kompeten.

\section{Pengujian Isothermis}

Prosedur yang digunakan untuk Uji Isothermis dalam Analisa Hot Ground dan atau Reactive Ground dengan mengacukan kepada AEISG (2007). Sample diuji terhadap bahan peledak ANFO, Emulsi, dan Emulsi + Inhibitor, pada suhu $55^{\circ} \mathrm{C}$. Pengamatan dilakukan secara visual dan rekam temperature reaksi dengan Thermo datalogger minimal 48 jam. Sample diklasifikasikan reactive apabila memenuhi kondisi, sebagai berikut:

1. Suhu sample akan naik minimum $2^{0} \mathrm{C}$ dari suhu tetapan awal.

2. Saat pengamatan visual muncul gas nitrogen oksida (berwarna cokelat).

3. Sample dengan tanda-tanda kereaktifan seperti huruf (b), akan tetapi kenaikan suhu kurang dari $2^{0} \mathrm{C}$, diklasifikasikan sebagai marginal reaktif.

Marginal reaktif dimungkinkan oleh kandungan sulfida pada sample yang sangat rendah, oksidasi udara yang terjadi terlalu awal pada sample, atau reaksi yang terjadi bukan merupakan reaksi oksidasi sulfida. 


\section{Pemantauan Temperature Lubang Panas (Elevated Temperature)}

Pengukuran suhu pada lubang ledak merupakan salah satu cara identifikasi awal untuk menentukan dengan tepat kondisi tanah pada lubang ledak tersebut. Prosedur yang dilakukan dalam kegiatan pemantauan temperatur lubang panas (metode Elevated Temperature) adalah sebagai berikut:

1. Memeriksa dan mempersiapkan daftar peralatan untuk keperluan pengukuran sebagai berikut:

a. Thermocouple Type $\mathrm{K}$

b. Thermometer Digital Type K

c. Alat dokumentasi \& pencatatan pengukuran

2. Memastikan Thermocouple Type $\mathrm{K}$ telah tersambung dengan Thermometer Digital Type $\mathrm{K}$.

3. Memastikan tidak ada kerusakan pada kabel Thermocouple Type K.

4. Memastikan lubang panas yang diukur merupakan lubang kering agar mengurangi risiko lubang collapse saat dilakukan pemantauan temperatur.

5. Memastikan tidak adanya material yang masuk ke dalam lubang panas saat dilakukannya pemantauan temperatur.

6. Menghindari memegang kabel Thermocouple Type $\mathrm{K}$ dengan cara membuat tali sebagai pengganti pegangan untuk memasukan alat ke dalam lubang panas (gunakan jenis tali nonplastic).

7. Memastikan proses pemantauan dilakukan sampai dengan nilai temperatur yang muncul pada Thermometer Digital Type K stabil.

8. Memastikan dilakukan pengukuran suhu pada top hole, middle hole dan bottom hole sesuai dengan form pemantauan temperature lubang panas.

9. Memastikan dilakukan oleh pekerja dan di bawah pengawas area yang kompeten.

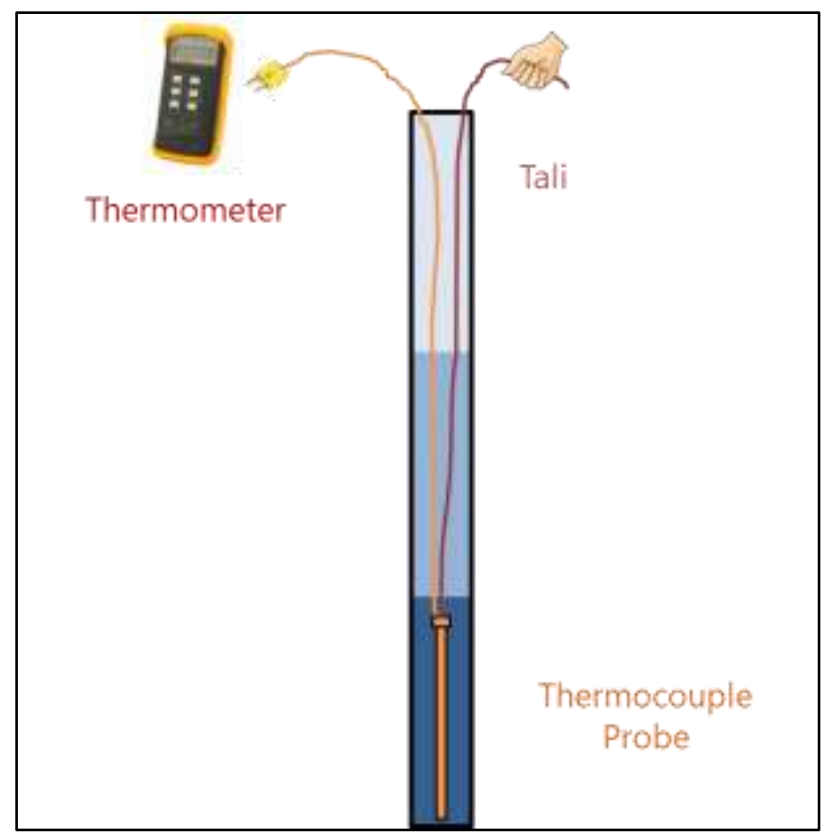

Gambar 3. Ilustrasi Pengukuran Elevated Temperature

\section{HASIL DAN PEMBAHASAN}

\section{Pengamatan Uji Isothermis}

Uji Isothermis dilakukan untuk mengetahui gambaran reaktivitas kondisi tanah / batuan (kandungan mineral sulfida yang reaktif terutama: iron \& copper sulphides). Jenis tanah / batuan ini kemudian secara proses kimiawi direaksikan dengan bulk explosives yang digunakan pada aktivitas peledakan untuk mengetahui diamati peningkatan temperaturnya. Bahan utama dari jenis bulk explosives ini adalah ammonium nitrate. Pengamatan dilakukan secara visual dan rekam temperature reaksi dengan Thermo datalogger. 
Tabel 1. Pengamatan Suhu

\begin{tabular}{|c|c|c|c|c|c|c|}
\hline \multicolumn{3}{|c|}{ Reaktan } & $\begin{array}{l}\text { Emulsi + } \\
\text { Inhibitor }\end{array}$ & ANFO & Emulsi & $\begin{array}{c}\text { Oil Bath/ } \\
\text { Tetapan } \\
\text { Awal }\end{array}$ \\
\hline \multicolumn{3}{|l|}{ Min } & 23,5 & 23,2 & 23,4 & 55 \\
\hline \multicolumn{3}{|l|}{ Max } & 55,3 & 56,1 & 56,3 & 55 \\
\hline \multicolumn{3}{|c|}{ Average } & 51,74 & 52,34 & 52,58 & 55 \\
\hline \multicolumn{3}{|c|}{ Delta Suhu } & 0,3 & 1,1 & 1,3 & 0 \\
\hline $\begin{array}{l}\text { Jam } \\
\text { ke- } n\end{array}$ & DATE & TIME & ${ }^{\circ} \mathrm{C}$ & ${ }^{\circ} \mathrm{C}$ & ${ }^{\circ} \mathrm{C}$ & ${ }^{\circ} \mathrm{C}$ \\
\hline 1 & $4 / 28 / 2020$ & $12: 54: 54$ & 24,9 & 25 & 25,3 & 55 \\
\hline 2 & $4 / 28 / 2020$ & $13: 09: 54$ & 24,5 & 24,1 & 24,4 & 55 \\
\hline 3 & $4 / 28 / 2020$ & $14: 09: 55$ & 45,6 & 46,5 & 46,9 & 55 \\
\hline 4 & $4 / 28 / 2020$ & $15: 09: 56$ & 50,9 & 51 & 51,4 & 55 \\
\hline 5 & $4 / 28 / 2020$ & $16: 09: 57$ & 51,2 & 51,7 & 52 & 55 \\
\hline 6 & $4 / 28 / 2020$ & $17: 09: 58$ & 51,7 & 52,3 & 52,5 & 55 \\
\hline 7 & $4 / 28 / 2020$ & $18: 09: 59$ & 51,5 & 52,1 & 52,3 & 55 \\
\hline 8 & $4 / 28 / 2020$ & $19: 10: 00$ & 51,5 & 52 & 52,3 & 55 \\
\hline 9 & $4 / 28 / 2020$ & 20:10:01 & 51,7 & 52,2 & 52,4 & 55 \\
\hline 10 & $4 / 28 / 2020$ & 21:10:02 & 51,5 & 52,2 & 52,4 & 55 \\
\hline 11 & $4 / 28 / 2020$ & 22:10:03 & 51,6 & 52,2 & 52,5 & 55 \\
\hline 12 & $4 / 28 / 2020$ & 23:10:04 & 51,6 & 52,1 & 52,4 & 55 \\
\hline 13 & $4 / 29 / 2020$ & $0: 10: 05$ & 51,5 & 52,1 & 52,3 & 55 \\
\hline 14 & $4 / 29 / 2020$ & 1:10:06 & 51,4 & 52 & 52,2 & 55 \\
\hline 15 & $4 / 29 / 2020$ & $2: 10: 07$ & 51,3 & 52 & 52,2 & 55 \\
\hline 16 & $4 / 29 / 2020$ & $3: 10: 08$ & 51,4 & 52 & 52,2 & 55 \\
\hline 17 & $4 / 29 / 2020$ & 4:10:09 & 52,4 & 53 & 53,3 & 55 \\
\hline 18 & $4 / 29 / 2020$ & $5: 10: 10$ & 52,8 & 53,4 & 53,7 & 55 \\
\hline 19 & $4 / 29 / 2020$ & $6: 10: 11$ & 52,8 & 53,4 & 53,6 & 55 \\
\hline 20 & $4 / 29 / 2020$ & $7: 10: 12$ & 52,6 & 53,3 & 53,5 & 55 \\
\hline 21 & $4 / 29 / 2020$ & $8: 10: 13$ & 48,4 & 48,8 & 49,1 & 55 \\
\hline 22 & $4 / 29 / 2020$ & $9: 10: 14$ & 47,1 & 47,5 & 47,7 & 55 \\
\hline 23 & $4 / 29 / 2020$ & 10:10:15 & 46,4 & 46,8 & 47,1 & 55 \\
\hline 24 & $4 / 29 / 2020$ & 11:10:16 & 49,6 & 50,3 & 50,7 & 55 \\
\hline 25 & $4 / 29 / 2020$ & $12: 10: 17$ & 53 & 53,6 & 54 & 55 \\
\hline
\end{tabular}


Indonesian Mining Professionals Journal Volume 3, Nomor 1, April 2021 : 31 - 40

\begin{tabular}{lllllll}
26 & $4 / 29 / 2020$ & $13: 10: 18$ & 54,1 & 54,7 & 55 & 55 \\
27 & $4 / 29 / 2020$ & $14: 10: 19$ & 54,9 & 55,7 & 55,8 & 55 \\
28 & $4 / 29 / 2020$ & $15: 10: 20$ & 55,3 & 56,1 & 56,3 & 55 \\
29 & $4 / 29 / 2020$ & $16: 10: 21$ & 53,1 & 53,8 & 53,9 & 55 \\
30 & $4 / 29 / 2020$ & $17: 10: 22$ & 52,9 & 53,6 & 53,7 & 55 \\
31 & $4 / 29 / 2020$ & $18: 10: 23$ & 52,9 & 53,7 & 53,8 & 55 \\
32 & $4 / 29 / 2020$ & $19: 10: 24$ & 52,7 & 53,5 & 53,6 & 55 \\
33 & $4 / 29 / 2020$ & $20: 10: 25$ & 52 & 52,7 & 52,8 & 55 \\
34 & $4 / 29 / 2020$ & $21: 10: 26$ & 51,3 & 52 & 52 & 55 \\
35 & $4 / 29 / 2020$ & $22: 10: 27$ & 51,3 & 52,1 & 52,2 & 55 \\
36 & $4 / 29 / 2020$ & $23: 10: 28$ & 54 & 54,5 & 54,9 & 55 \\
37 & $4 / 29 / 2020$ & $0: 10: 28$ & 54 & 54,8 & 55,1 & 55 \\
38 & $4 / 29 / 2020$ & $1: 10: 28$ & 53 & 53,7 & 53,7 & 55 \\
39 & $4 / 29 / 2020$ & $2: 10: 28$ & 54,1 & 54,7 & 55 & 55 \\
40 & $4 / 29 / 2020$ & $3: 10: 28$ & 54,1 & 54,6 & 55 & 55 \\
41 & $4 / 29 / 2020$ & $4: 10: 28$ & 54,2 & 54,8 & 55 & 55 \\
42 & $4 / 29 / 2020$ & $5: 10: 28$ & 54,2 & 54,7 & 55 & 55 \\
43 & $4 / 29 / 2020$ & $6: 10: 28$ & 54,1 & 54,7 & 55 & 55 \\
44 & $4 / 29 / 2020$ & $7: 10: 28$ & 52,9 & 53,6 & 53,8 & 55 \\
45 & $4 / 29 / 2020$ & $8: 10: 28$ & 54,2 & 54,7 & 55 & 55 \\
46 & $4 / 29 / 2020$ & $9: 10: 28$ & 54,2 & 54,8 & 55,1 & 55 \\
47 & $4 / 29 / 2020$ & $10: 10: 28$ & 54,1 & 54,6 & 55 & 55 \\
48 & $4 / 29 / 2020$ & $11: 10: 28$ & 54,1 & 54,7 & 55 & 55 \\
49 & $4 / 29 / 2020$ & $12: 10: 28$ & 54 & 54,5 & 54,9 & 55 \\
50 & $4 / 29 / 2020$ & $13: 10: 28$ & 53,1 & 53,9 & 54,2 & 55 \\
51 & $4 / 29 / 2020$ & $14: 10: 28$ & 54,1 & 54,7 & 55 & 55 \\
52 & $4 / 29 / 2020$ & $14: 52: 28$ & 54,2 & 54,8 & 55 & 55 \\
\hline
\end{tabular}




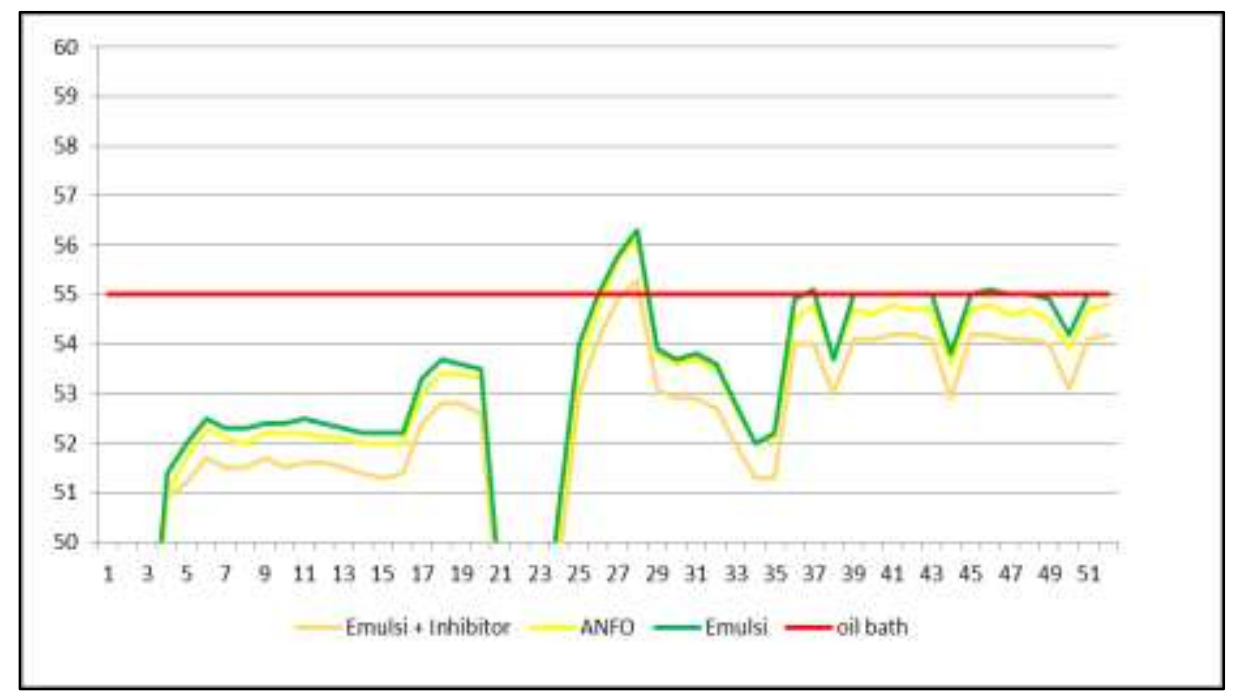

Gambar 4. Grafik Pengamatan Suhu
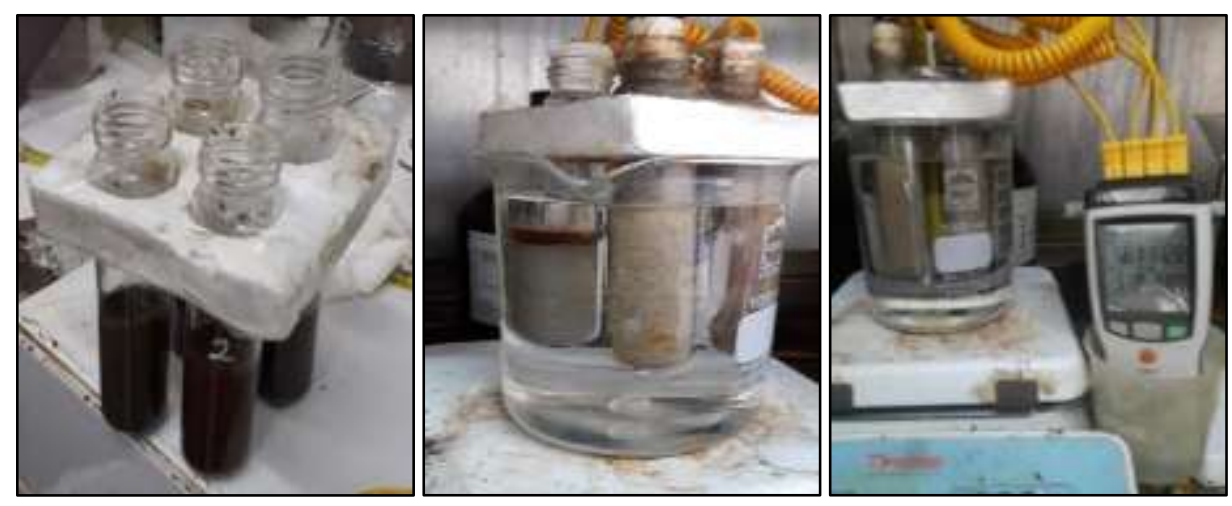

Gambar 5. Pengamatan Suhu

Catatan: Kadar Inhibitor $\pm 8 \%(\mathrm{w} / \mathrm{w})$ terhadap Total Emulsi

Tabel 2. Hasil Pengamatan Suhu

\begin{tabular}{|c|c|c|c|c|c|}
\hline Reactan Handak & Min & $\max$ & average & $\begin{array}{c}\text { Delta-T } \\
\text { Terhadap } \\
\text { tetapan (55 } \\
\left.{ }^{0} \mathrm{C}\right)\end{array}$ & $\begin{array}{c}\text { Pengamatan } \\
\text { Visual }\end{array}$ \\
\hline ANFO & 23.20 & 56.10 & 52.35 & 1.10 & $\begin{array}{c}\text { permukaan } \\
\text { sample naik, tidak } \\
\text { terlihat rilis gas NOx }\end{array}$ \\
\hline EMULSI & 23.40 & 56.30 & 52.59 & 1.30 & $\begin{array}{c}\text { permukaan } \\
\text { sample naik, tidak } \\
\text { terlihat rilis gas NOx }\end{array}$ \\
\hline EMULSI + Inhibitor & 23.50 & 55.30 & 51.74 & 0.30 & $\begin{array}{l}\text { permukaan sample } \\
\text { tidak naik }\end{array}$ \\
\hline
\end{tabular}

Dari data rekaman pengamatan suhu dan pengamatan visual selama $2 \times 24$ jam, dapat disimpulkan bahwa batuan bersifat tidak reaktif, baik terhadap ANFO maupun terhadap Emulsi. 
Selama pengamatan memang terjadi kenaikan level sample batuan dari posisi semula, dan terjadi juga kenaikan suhu namun belum melebihi $2^{\circ} \mathrm{C}$.

\section{Pengukuran Elevated Temperature}

Pengukuran Elevated Temperature dilakukan berdasarkan simulasi block pada boundary area yang terindikasi Hot Ground yang telah disesuaikan dengan dengan prioritas sequence penambangan di Pit 1 secara short term. Pengukuran data diawali dengan melakukan menentukan titik pengambilan sample pengukuran Elevated Temperature pada block yang akan diambil datanya untuk mempermudah persiapan lokasi untuk dilakukan pengeboran.

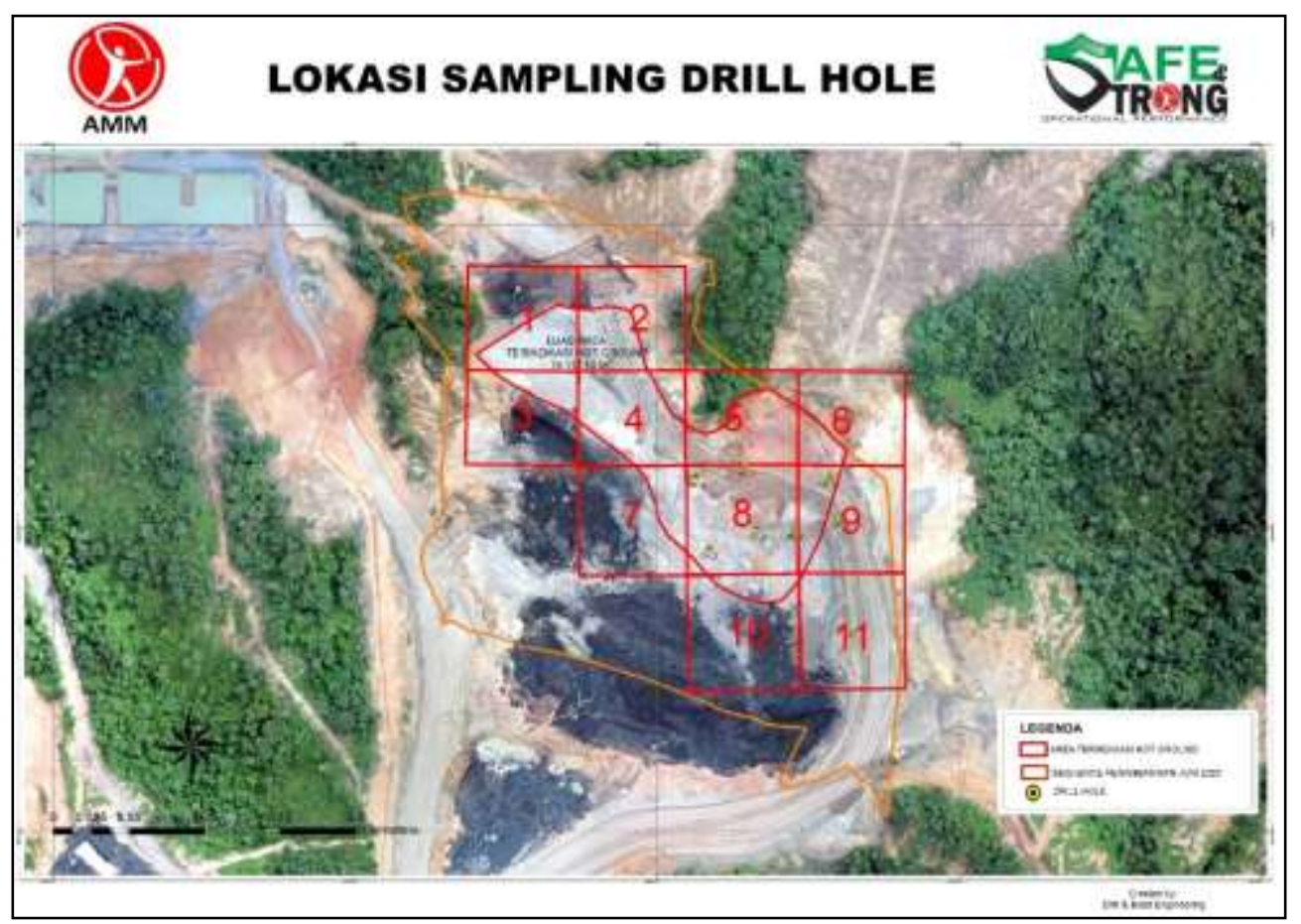

Gambar 6. Peta Lokasi Pengukuran Elevated Temperature

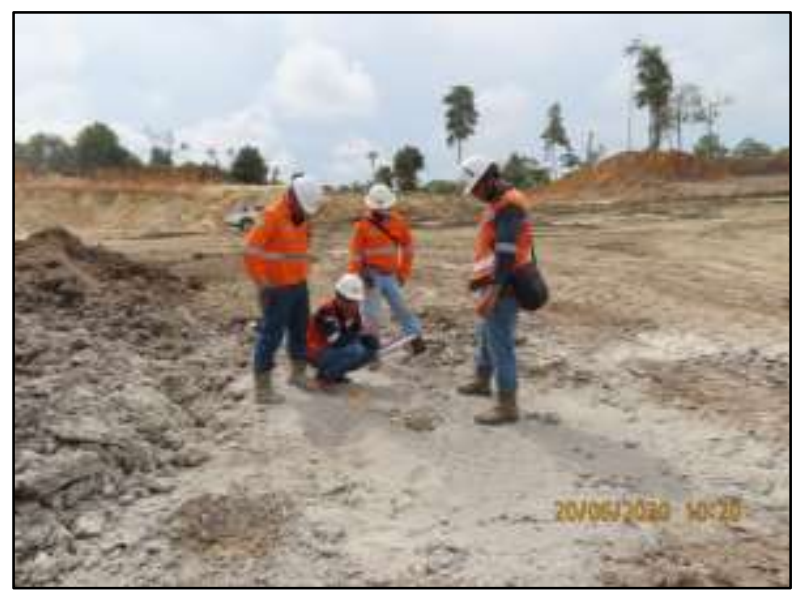

Gambar 7. Kegiatan Pengukuran Elevated Temperature

Tabel 3. Hasil Pengamatan Suhu

\begin{tabular}{cccccccc}
\hline No. Hole & \multirow{2}{*}{ Block } & Condition & Hole Depth & \multicolumn{3}{c}{ Temperature $\left({ }^{\mathbf{0}} \mathbf{C}\right)$} & \multirow{2}{*}{ Notes } \\
& $($ DrylWet $)$ & $(\mathrm{m})$ & Top & Middle & Bottom & \\
\hline 1 & 8 & Dry & 6 & 180,7 & 203,7 & 223,4 & - \\
2 & 8 & Dry & 4 & 110,2 & 121,7 & 125,7 & - \\
3 & 8 & Dry & 1,5 & - & - & 74,4 & Batang bor terjepit \\
\hline
\end{tabular}




\begin{tabular}{|c|c|c|c|c|c|c|c|}
\hline \multirow{2}{*}{ No. Hole } & \multirow{2}{*}{ Block } & \multirow{2}{*}{$\begin{array}{l}\text { Condition } \\
\text { (Dry/Wet) }\end{array}$} & \multirow{2}{*}{$\begin{array}{l}\text { Hole Depth } \\
\text { (m) }\end{array}$} & \multicolumn{3}{|c|}{ Temperature $\left({ }^{0} \mathrm{C}\right)$} & \multirow{2}{*}{ Notes } \\
\hline & & & & Top & Middle & Bottom & \\
\hline 4 & 8 & Dry & 3,5 & 165,1 & 170 & 189,4 & - \\
\hline 5 & 8 & Dry & 3,5 & 45,5 & 47,3 & 48,8 & - \\
\hline 6 & 9 & Dry & 6,5 & 62,1 & 62,8 & 69,3 & - \\
\hline 7 & 9 & Dry & 6 & 41,5 & 42,8 & 45,1 & - \\
\hline
\end{tabular}

\section{C.3. Rekomendasi dan Klasifikasi Hasil Pengukuran Elevated Temperature}

Rekomendasi dan klasifikasi hasil pengukuran elevated temperature adalah sebagai berikut:

1. Jika hasil pengukuran pada bagian top hole, middle hole dan bottom hole $\leq 55^{\circ} \mathrm{C}$ maka pelaksanaan pengisian bahan peledak bisa dilakukan dengan normal sesuai dengan prosedur yang berlaku.

2. Jika hasil pengukuran pada bagian top hole dan atau middle hole $\geq 55^{\circ}-65^{\circ} \mathrm{C}$ :

a. Menggunakan bahan peledak jenis emulsion.

b. Pengisian dilakukan secara instant, tidak lebih dari 15 menit sebelum peledakan dilakukan. c. Proses pengisian direkomendasikan di lakukan dengan bottom priming.

d. In-hole detonator shocktube nya diberi tambahan protector (misal: pvc $1 / 2$ inch) dan posisi penempatan in-hole detonator shocktube yang sudah diberi protector ditempatkan ditengah dari emulsion stemming material (center of hole) \& tidak menempel ke dinding lubang.

3. Jika hasil pengukuran pada bagian bottom hole $\geq 55^{\circ}-65^{\circ} \mathrm{C}$ : tidak direkomendasikan untuk di isi.

4. Jika hasil pengukuran pada bagian top hole, middle hole, dan atau bottom hole $\geq 65^{\circ} \mathrm{C}$ : tidak direkomendasikan untuk di isi.

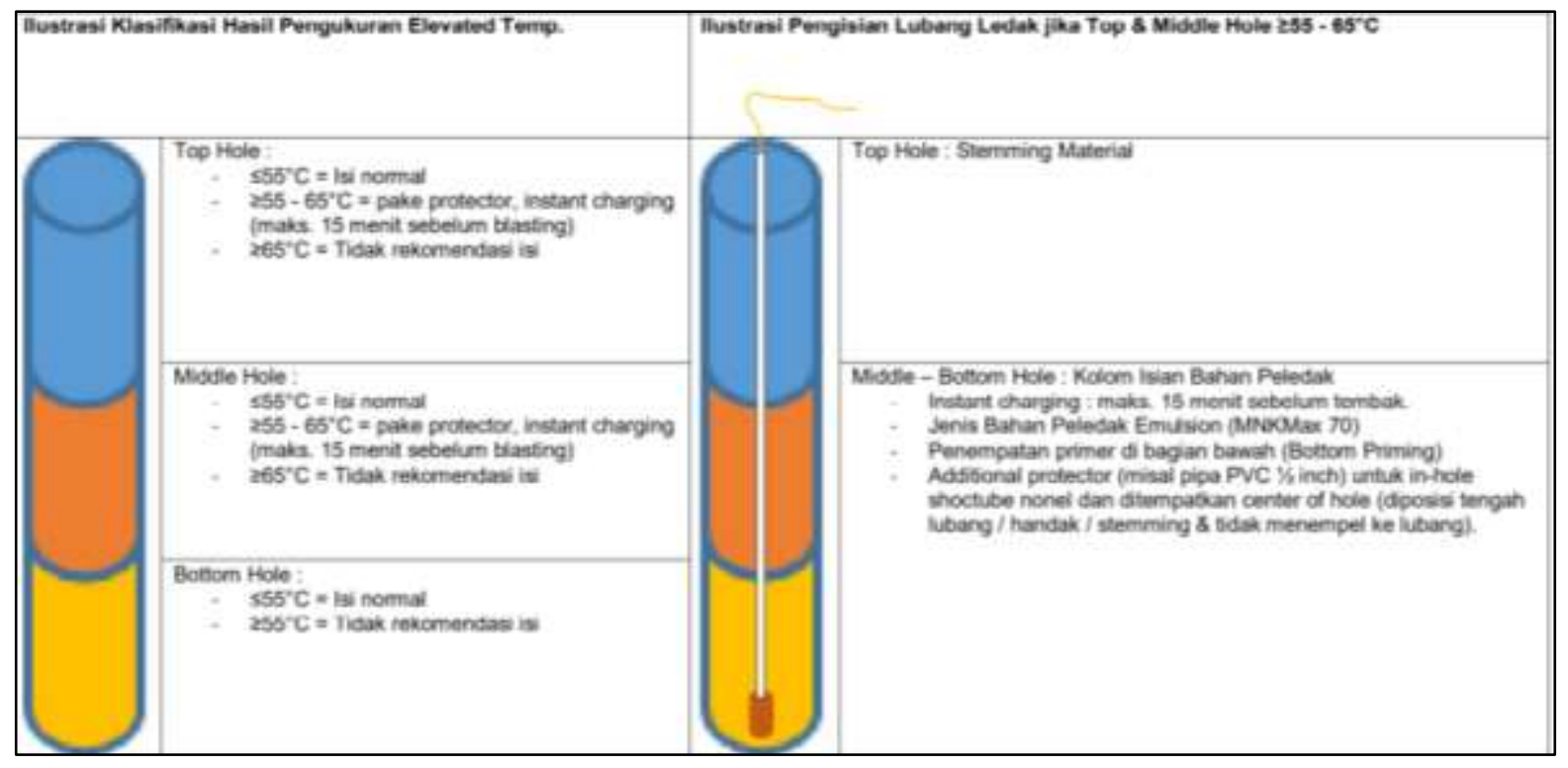

Gambar 8. Ilustrasi Rekomendasi dan Klasfikasi Hasil Pengukuran Elevated Temperature

\section{KESIMPULAN}

1. Dengan tidak teridentifikasinya sample batuan dalam golongan batuan reaktif, maka sample batuan yang didapat dari Pit 1 Jobsite ABP
Energy tergolong pada kategori "kondisi tanah menimbulkan lubang panas tetapi tanah tidak reaktif bila diisi bahan peledak".

2. Rekomendasi sesuai hasil pengukuran Elevated Temperature pada block 8 dan 9 
Tabel 4. Rekomendasi Manajemen Hot Ground

\begin{tabular}{|c|c|c|}
\hline Block & Average Elevated Temperature $\left({ }^{\circ} \mathrm{C}\right)$ & Recommendation \\
\hline 8 & $\begin{array}{c}\text { Top hole : } 125,4 \\
\text { Middle hole : } 135,7 \\
\text { Bottom hole : } 132,3\end{array}$ & Tidak direkomendasikan untuk diisi bahan peledak \\
\hline 9 & $\begin{array}{l}\text { Top hole : } 51,8 \\
\text { Middle hole : } 52,8 \\
\text { Bottom hole : } 57,2\end{array}$ & $\begin{array}{c}\text { Memerlukan tambahan sample hole pengukuran elevated } \\
\text { temperature jika lokasi tersebut direncanakan untuk } \\
\text { dijadikan lokasi peledakan (sample lokasi belum } \\
\text { representative \& minim) }\end{array}$ \\
\hline \multicolumn{2}{|c|}{$\begin{array}{l}\text { UCAPAN TERIMA KASIH } \\
\text { Penulis ingin mengucapkan terima kasih kepada PT. }\end{array}$} & $\begin{array}{l}\text { Pratama sebagai pelanggan PT.Multi Nitrotama } \\
\text { Kimia yang memberikan dukungan dan persetujuan } \\
\text { mereka untuk menerbitkan makalah ini. }\end{array}$ \\
\hline
\end{tabular}

\section{DAFTAR PUSTAKA}

Hustrulid. W. (1999): Blasting Principles for Open Pit Mining, Volume 1. (pp. 272-273). Brookfield: A.A. Balkema. Rotterdam.

Australian Explosives Industry And Safety Group (AEISG). (2017) : Elevated Temperature and Reactive Ground, Edition 4 